\title{
NM23 PROTEIN EXPRESSION IN COLORECTAL CARCINOMA USING TMA (TISSUE MICROARRAY): association with metastases and survival
}

\author{
Levindo Alves de OLIVEIRA'1', Ricardo ARTIGIANI-NETO², Daniel Reis WAISBERG', \\ Luis Cesar FERNANDES ${ }^{1}$, Flávio de Oliveira LIMA² and Jaques WAISBERG' ${ }^{1}$
}

\begin{abstract}
Context - NM23, a metastasis suppressor gene, may be associated with prognosis in patients with colorectal carcinoma. Objective - To analyze NM23 expression and its association with the presence of lymph node and liver metastases and survival in patients operated on for colorectal carcinoma. Methods - One hundred thirty patients operated on for colorectal carcinoma were investigated. Tissue microarray blocks containing neoplastic tissue and tumor-adjacent non-neoplastic mucosa were obtained and analyzed by immunohistochemical staining using a monoclonal anti-NM23 antibody. Immunohistochemical expression was assessed using a semiquantitative scoring method, counting the percentage of stained cells. The results were compared regarding morphological and histological characteristics of the colorectal carcinoma, presence of lymph node and liver metastases, tumor staging, and patient survival. Statistical analysis was performed using the Mann-Whitney test, the Kruskal-Wallis test and Fisher's exact test. Survival analysis was performed using the Kaplan-Meier method and the log-rank test. Results - NM23 expression was higher in colorectal carcinoma tissue than in adjacent non-neoplastic mucosa $(P<0.0001)$. NM23 protein expression did not correlate with degree of cell differentiation $(P=0.57)$, vascular invasion $(P=0.85)$, lymphatic invasion $(P=0.41)$, perineural infiltration $(P=0.46)$, staging $(P$ $=0.19)$, lymph node metastases $(P=0.08)$, or liver metastases $(P=0.59)$. Disease-free survival showed significant association $(P=$ 0.01 ) with the intensity of NM23 protein immunohistochemical expression in colorectal carcinoma tissue, whereas overall survival showed no association with NM23 protein expression $(P=0.13)$. Conclusions - NM23 protein expression was higher in neoplastic colorectal carcinoma tissue than in adjacent non-neoplastic mucosa, showing no correlation with morphological aspects, presence of lymph node or liver metastases, colorectal carcinoma staging, or overall survival. Disease-free survival was higher in patients with increased NM23 expression.
\end{abstract}

HEADINGS - Colorectal neoplasms. Carcinoma. Tumor markers, biological. Antigens, CD. NM23 nucleoside diphosphate kinases. Prognosis.

\section{INTRODUCTION}

Colorectal carcinoma is one of the most common cancers in the Western world and is becoming increasingly prevalent ${ }^{(5,9,15)}$. Despite advances in surgical management and complementary treatment of these tumors, overall mortality has not decreased significantly over recent years ${ }^{(1,4,5,29)}$.

The most significant prognostic factor in colorectal carcinoma is tumor staging at initial diagnosis. Depth of tumor penetration into the intestinal wall, lymph node involvement and presence of metastases are the most reliable indicators of survival in colorectal carcinoma $^{(3,9,15)}$.

Although subjected to different cancer screening procedures, several patients show a more advanced stage at surgery, and the overall 5-year survival rate reaches only $50 \%$ of colorectal carcinoma patients despite having resectable disease ${ }^{(9,15)}$. Metastasis is the main cause of death in this group, leading to locoregional or distant recurrence in late-stage tumors.

Studies ${ }^{(3,21,29)}$ have investigated factors that may reduce morbidity and mortality from colorectal cancer, with a special emphasis on tumor markers. Despite the relatively large number of studies analyzing tumor markers, only a few of them are currently used in clinical practice. However, high costs and low sensitivity and specificity limit the routine use of these markers in a clinical setting ${ }^{(5,11,19)}$.

Most prognostic parameters based on the immunohistochemical expression of tumor markers require neoplastic tissue samples and, therefore, can only be assessed postoperatively or after obtaining tissue for biopsy. Moreover, reproducibility of results

Departments of Surgery and ${ }^{2}$ Pathology, São Paulo Federal University/Escola Paulista de Medicina, São Paulo, Brazil.

Correspondence: Prof. Jaques Waisberg - Rua das Figueiras, 550 - apt.134 - 09080-300 - Santo André, SP, Brazil. E-mail: jaqueswaisberg@uol.com.br 
may vary ${ }^{(13,17,23,29)}$. Nevertheless, the study of tumor markers in neoplastic tissue is particularly interesting, because it allows analysis of tumor cells and intraindividual biological variability, providing a high degree of biological specificity concerning the cancer under study. Within this context, one may speculate that determining the immunohistochemical expression of markers in colorectal carcinoma tissue has the potential to provide prognostic information, even in non-advanced stages ${ }^{(2)}$.

The NM23 gene is located on chromosome 17 and produces two proteins, NM23-H1 and NM23-H2 ${ }^{(11,14,18,33,36)}$. Identified as a metastasis suppressor gene, NM23 was first isolated in murine melanoma cell lines ${ }^{(11)}$. Campo et al. ${ }^{(11)}$ associated low tissue immunohistochemical expression of these proteins with poor prognosis in colorectal carcinoma patients. On the other hand, Bazan et al. ${ }^{(6)}$ found no correlation between the reduced tissue expression of this marker and prognosis in colorectal cancer. Other studies have shown conflicting results concerning the association between NM23 expression in colorectal carcinoma tissue and tumor prognosis ${ }^{(6,8,10,12,30)}$.

Due to the high incidence of colorectal cancer and the difficulty in establishing a prognosis for these patients, especially in tumor-node-metastasis (TNM) stages II and III, the study of tumor markers that may predict prognosis is of utmost importance. The objective of this study was to analyze NM23 expression and its association with anatomicopathologic aspects of tumors, presence of lymph node and liver metastases, and survival in patients operated on for colorectal carcinoma, as well as to contribute to a better understanding of the biological dynamics of the NM23 protein in colorectal carcinoma by measuring its tissue immunohistochemical expression.

\section{METHODS}

The study was approved by the Research Ethics Committee of Universidade Federal de São Paulo (UNIFESP), São Paulo, SP, Brazil, under protocol no. 1958/07.

Inclusion criteria were adult patients with colorectal carcinoma confirmed by anatomicopathologic examination. Exclusion criteria were the presence of hereditary colorectal cancer, Crohn's disease, ulcerative colitis, metachronous colorectal cancer, or any other previously treated neoplasm.

Biodemographic variables included age at diagnosis and gender. With regard to neoplastic lesions, we analyzed tumor site, macroscopic and microscopic characteristics, and stage of primary lesion. The following patient-related events were also analyzed: type of surgical intervention, presence of synchronous metastases, follow-up period, disease-free period, tumor relapse, death, mortality rate, and overall survival.

Overall survival time was calculated from the date of surgery to the last follow-up visit or date of death. Diseasefree survival was defined as the interval after curative surgery during which there was no evidence of tumor relapse.

NM23 expression was assessed on paraffin-embedded tissue sections by immunohistochemical analysis in colorectal carcinoma tissue and adjacent non-neoplastic colorectal tissue. The relationship of the intensity of NM23 tissue expression with anatomicopathologic characteristics of the tumor and outcome of patients was then obtained.

The study population consisted of 130 patients $(65 \mathrm{men}$ and 65 women) operated on for colorectal carcinoma between October 2001 and March 2005 at the Proctology Service of UNIFESP. Patients' mean age was 64.2 years (29 to 90 years). The TNM classification system (UICC, 2002) was used for tumor staging.

Prognostic criteria were represented by the following parameters: tumor relapse, overall mortality, overall survival, and disease-free period. The occurrence of relapse was confirmed by complementary tests or laparotomy.

Patient follow-up ranged from 1 to 47 months (mean of 25.4 months). The mean follow-up period for patients treated with curative intent was 36.4 months.

For the tissue microarray (TMA), all histological hematoxylin and eosin (H-E)-stained sections of colorectal carcinoma were examined by two pathologists. Specimens were assessed for diagnostic confirmation, histological grade and selection of sites for TMA core removal. A Beecher ${ }^{\mathrm{TM}}$ tissue arrayer device (Beecher Instruments, Silver Spring, USA) was used to construct the TMA, according to the standard technique ${ }^{(1)}$.

Using an adhesive-coated tape system (Instrumedics Inc, Hackensak, USA), 4- $\mu \mathrm{m}$ sections were cut and transferred to adhesive-coated slides. A small roller was used to press the section flat against the tape, which was then placed on a resin-coated slide and pressed using the same roller for better adhesion of the section to the surface. These slides were then exposed to ultraviolet light for 20 minutes. The slides were dried and the adhesive tapes were removed.

To ensure the representative of each area of the donor block, at least two samples were collected, each of them being represented in two different sites in the same recipient block, resulting in a mirror-image representation of the samples. Whenever the samples, even with a mirror-image representation, were not representative examples of the tissue in question, new samples were collected from the donor block and an additional recipient block was constructed. The slides were then submitted to immunohistochemistry.

Immunohistochemical analysis was performed using the streptavidin-biotin-peroxidase staining technique with a monoclonal anti-NM23 antibody (Neomarkers, USA), at 1:1000 dilution. This antibody has affinity for both $\mathrm{H} 1$ and $\mathrm{H} 2$ components of the NM23 protein.

Positive results were visible as brown cytoplasmic or nuclear staining for the antibody under study. Slides containing histological sections of NM23 positive colorectal tissue were used as positive controls ${ }^{(26)}$. The same slides were used as negative controls by removing the primary antibody from the staining reaction.

The sections were examined using a slide scanner (ScanScope CS System, Aperio Technologies, UK), assessing the percentage of cells with a positive reaction in 10 microscopic fields at 400 magnification (x400). In the assessment of immunohistochemical markers, cells showing dubious staining and non-tumor cells were excluded. Assessment was 
performed independently and in a blinded fashion by two experienced pathologists. In cases of conflicting observations, which corresponded to less than $10 \%$ of the total sample, a consensus was achieved between both pathologists at joint reevaluation of their data previously obtained independently.

The criteria used to assess NM23 expression ${ }^{(26)}$ were based on the number of stained cells, and scores were assigned as follows: score $0=10 \%$ or less, score $1=11 \%$ to $25 \%$, score $2=$ $26 \%$ to $50 \%$, and score $3=51 \%$ or more stained neoplastic cells. The assessment of NM23 immunohistochemical expression was performed in tumor tissue and in non-neoplastic mucosa obtained from region adjacent to the tumor. Scores 0 to 2 were considered as NM23 negative (protein downexpression), and score 3 was considered as NM23 positive (protein overexpression).

The slides were scanned and images were captured by a camera (Samsung, South Korea), coupled with a microscope (Olympus Bx 40, Japan), using Win TV 32 software. Positive and negative staining was identified in tumor tissue and nonneoplastic mucosa (Figures 1, 2, 3).

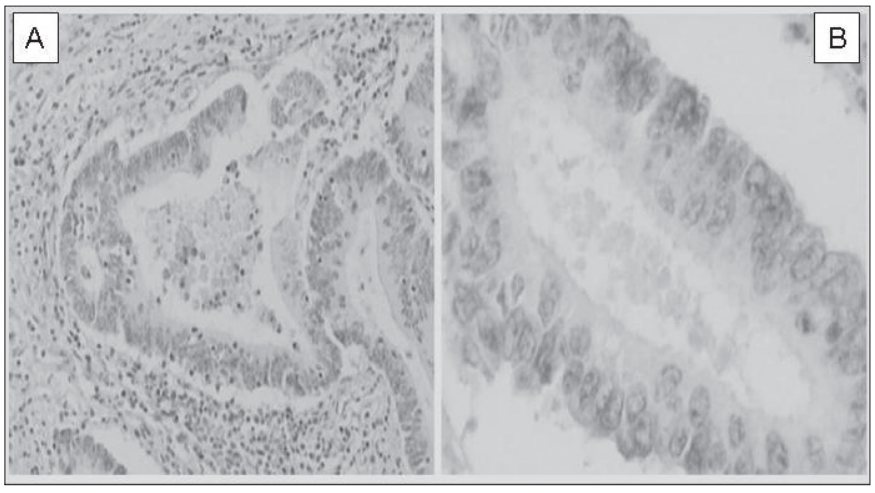

FIGURE 1. Immunohistochemical of colorectal carcinoma tissue with no immunoexpression for the anti-NM23 antibody (A - 100X and B - 400X)

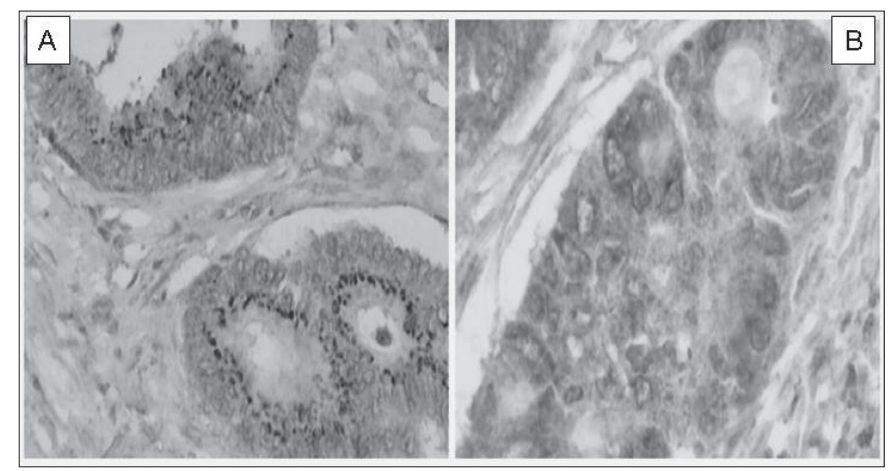

FIGURE 2. Immunohistochemical of colorectal carcinoma tissue with cytoplasmic immunoexpression for the anti-NM23 antibody (A - 100X and $\mathrm{B}-400 \mathrm{X}$ )

Quantitative variables were expressed as means. The variables were analyzed by the Mann-Whitney test, Spearman's test and Fisher's exact test. The Kruskal-Wallis test was used

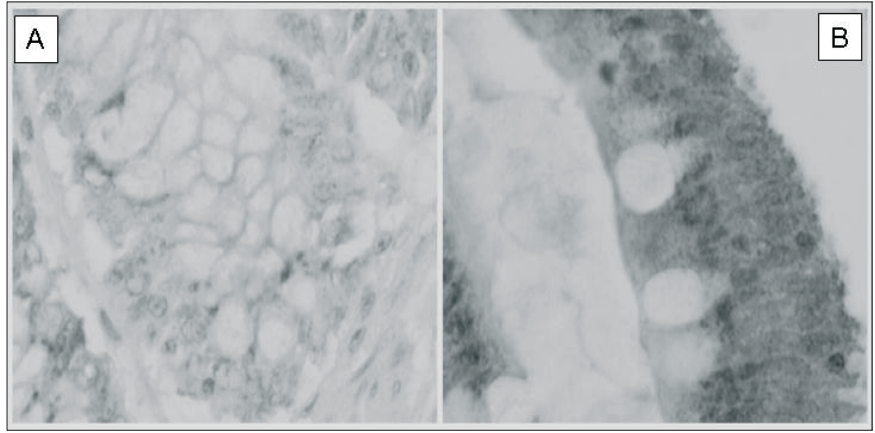

FIGURE 3. Immunohistochemical of non-neoplastic mucosa with the anti-NM23 antibody. A: negative immunoexpression (400X). B: positive immunoexpression (400X)

in the analysis of variance. Survival analysis was performed using the Kaplan-Meier method, and survival curves were compared using the log-rank test. Statistical analysis was performed using the Prism 4.0 statistical software (GraphPad Software Inc., USA), and the level of significance was set at $P \leq 0.05$ (5\%).

\section{RESULTS}

Eighty-two (63.1\%) patients underwent curative surgery and the remaining $48(35.9 \%)$ patients underwent palliative operation. Regarding tumor site, $83(63.9 \%)$ tumors were in the rectum and $47(36.1 \%)$ were in the colon.

The following surgical procedures were performed: rectosigmoidectomy in $59(45.4 \%)$ patients, right colectomy in $38(29.2 \%)$, laparotomy with or without colostomy in $11(8.5 \%)$, abdominoperineal resection in $10(7.7 \%)$, total colectomy in $10(7.7 \%)$, left colectomy in $9(6.9 \%)$, and transversectomy in $3(2.3 \%)$.

Thirty-four (37.8\%) patients died, and loss to follow-up occurred in 23 cases $(17.6 \%)$.

Concerning disease-free period, $10(12.2 \%)$ out of the 82 patients who underwent curative surgery experienced disease relapse. Of these patients, $4(40 \%)$ showed local recurrence, 4 $(40 \%)$ local and distant recurrence, and $2(30 \%)$ only distant recurrence. In distant recurrence, the liver was the most commonly affected site, accounting for $3(30 \%)$ cases.

Regarding the immunohistochemical analysis performed in 93 patients, NM23 immunohistochemical expression was significantly higher in tumor tissue $(P<0.0001)$ than in non-neoplastic colorectal mucosa (Figure 4). In $82(88.2 \%)$ patients, NM23 expression in tumor cells scored 3 (protein overexpression), whereas in $11(11.8 \%)$ patients, NM23 expression scored less than 3 (protein downexpression).

Table 1 shows immunohistochemical expression of the NM23 protein in relation to the main clinicopathological parameters.

NM23 expression showed no significant differences regarding large bowel location $(P=0.79)$, degree of cell differentiation $(P=0.57)$, vascular invasion $(P=0.86)$, lymphatic invasion $(P=0.41)$, perineural invasion $(P=0.46)$, lymph node 


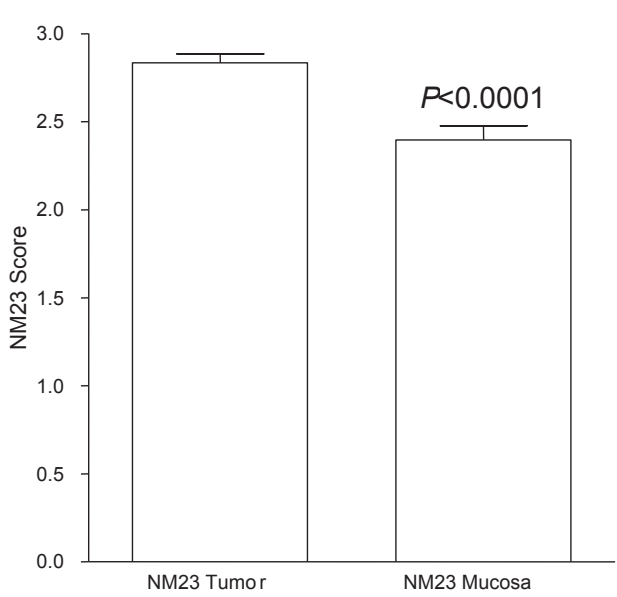

FIGURE 4. Intensity of NM23 marker immunoexpression in tumor tissue and in non-neoplastic colorectal mucosa

TABLE 1. Relationship between the main clinicopathological parameters of patients operated on for colorectal carcinoma and tissue immunohistochemical expression of the NM23 protein ( $P$ value)

\begin{tabular}{lcc}
\hline Large bowel location & $\mathrm{n}(\%)$ & $P=0.79(\mathrm{NS})$ \\
\hline Colon & $52(53.6 \%)$ & \\
Rectum & $45(46.4 \%)$ & \\
Total & $97(100 \%)$ & \\
\hline Degree of cell differentiation & & \\
\hline High & $44(40.4 \%)$ & \\
Moderate & $58(53.2 \%)$ & \\
Low & $7(6.4 \%)$ & \\
Total & $109(100 \%)$ & \\
\hline Vascular invasion & & \\
\hline Present & $23(21.1 \%)$ & \\
Absent & $86(78.9 \%)$ & \\
Total & $109(100 \%)$ & \\
\hline Lymphatic invasion & & \\
\hline Present & $65(59.6 \%)$ & \\
Absent & $44(40.4 \%)$ & \\
Total & $109(100 \%)$ & \\
\hline Perineural invasion & & \\
\hline Present & $35(32.1 \%)$ & \\
Absent & $7467(9 \%)$ & \\
Total & $109(100 \%)$ & \\
\hline Lymph node metastasis & & \\
\hline Present & & \\
Absent & & \\
Total & $50(46.3 \%)$ & \\
\hline Liver metastasis & $58(53.7 \%)$ & \\
\hline Present & $108(100 \%)$ & \\
Absent & & \\
& $27(30.0 \%)$ & \\
\hline TNM staging & $63(70.0 \%)$ & \\
\hline I & $90(100 \%)$ & \\
II & & \\
III & $29(9.0 \%)$ & \\
IV & $35(35.0 \%)$ & \\
\hline Total & $27(27.0 \%)$ & \\
\hline & $100(100 \%)$ & \\
& & \\
\hline
\end{tabular}

NS = not significant;

TNM $=$ tumor-node-metastasis

* Significant metastasis $(P=0.08)$, liver metastasis $(P=0.31)$, or TNM staging classification $(P=0.19)$ of colorectal carcinoma.

The mean follow-up period was 25.4 months ( 1 to 47 months). Disease-free survival was significantly higher $(P$ $=0.01)$ in NM23 positive patients who underwent curative surgery. Estimated disease-free survival was 17\% for NM23 negative patients (scores 0 to 2 ) vs $61.1 \%$ for NM23 positive patients (score 3) (Figure 5).

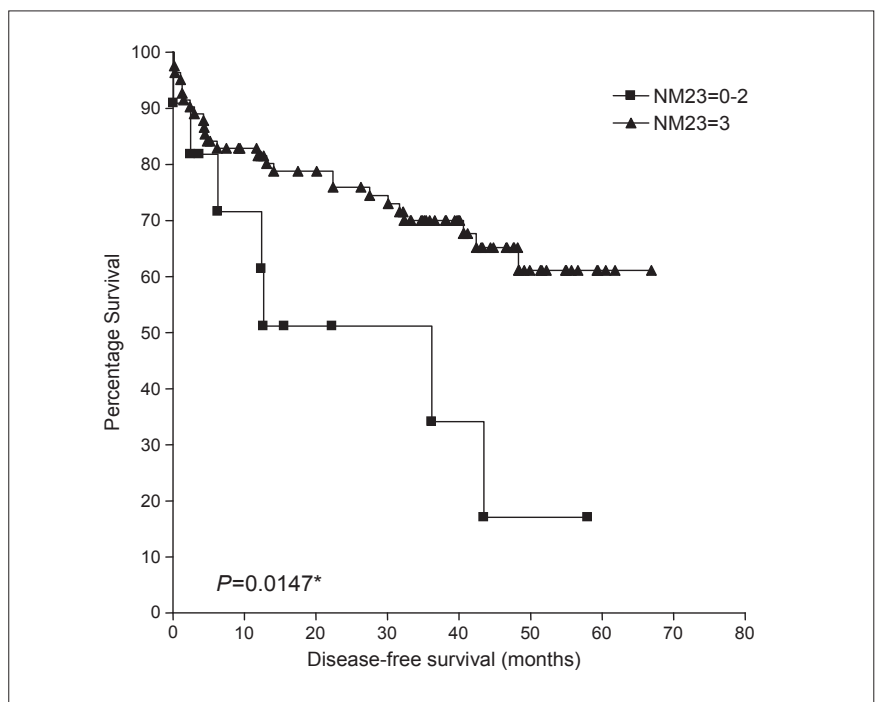

FIGURE 5. Disease-free survival according to NM23 marker expression in colorectal carcinoma tissue (Kaplan-Meier method)

Estimated 5-year survival was 49\% among NM23 negative patients (scores 0 to 2 ) and $65 \%$ among NM23 positive patients (score 3), but this difference was not statistically significant $(P=0.13)$ (Figure 6).

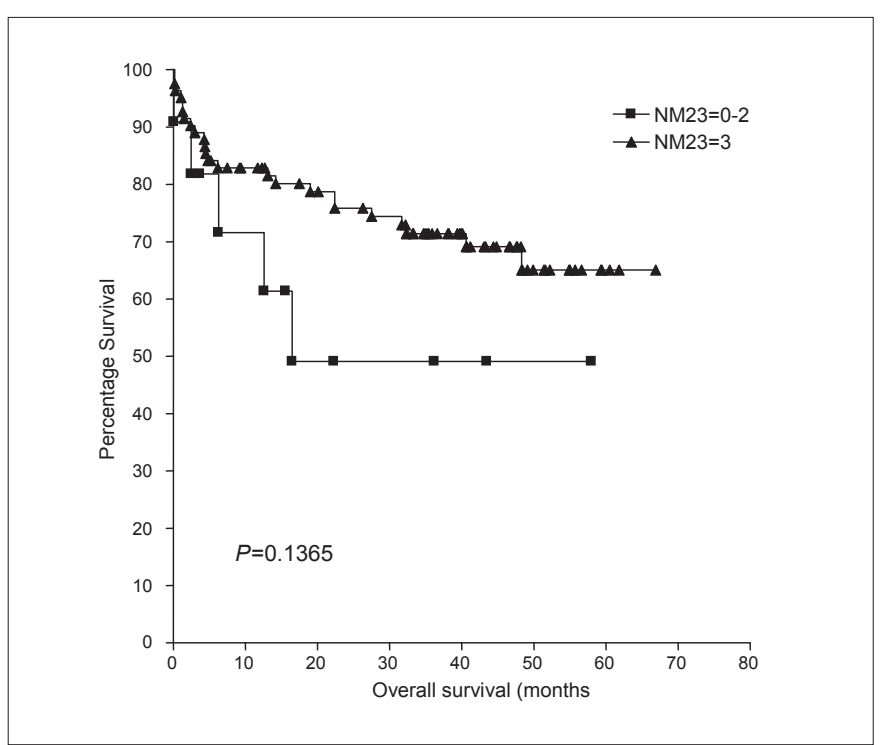

FIGURE 6. Overall patient survival according to NM23 marker expression in colorectal carcinoma tissue (Kaplan-Meier method) 


\section{DISCUSSION}

Many studies $(2,7,32,34,37,41)$ have used tissue expression of the NM23 protein to identify prognostic predictors of colorectal carcinoma. However, controversy remains about the prognostic value of the tissue expression of this marker ${ }^{(2)}$.

The present study employed TMA given the wide applicability of this method and cost savings due to reduced reagent consumption, leading to a rapid process of immunohistochemical staining ${ }^{(1)}$.

Kononen et al. ${ }^{(25)}$ developed an array-based high-throughput technique that facilitates gene expression and copy number surveys of very large numbers of tumors. In this technique, sections of the microarray provide targets for parallel in situ detection of DNA, RNA and protein targets in each specimen on the array, and consecutive sections allow the rapid analysis of hundreds of molecular markers in the same set of specimens.

Given the intense NM23 expression in the neoplastic tissue in our series, there were only three instances in which lesions showed less than $10 \%$ stained cells. The total sample was, therefore, divided into two groups: samples with weak expression, in which less than $50 \%$ of cells were stained; and samples with strong expression, showing more than $50 \%$ stained cells. Nevertheless, no consensus has been reached regarding the percentage threshold at which marker expression is deemed positive ${ }^{(2,31,41)}$. Berney et al. ${ }^{(7)}$ investigated several tumor markers, including the NM23 protein. These authors considered five levels of marker expression, taking into account intensity of expression and percentage of stained cells, a classification similar to that used by Brenner et al. ${ }^{(10)}$.

Sarris and $\mathrm{Lee}^{(35)}$ analyzed immunohistochemical expression of the NM23 protein in relation to the occurrence of metastases, using the following parameters: weak expression (less than 30\% stained cells); moderate expression (31\%-75\% stained cells); and strong expression (more than $75 \%$ stained cells). Garinis et al. ${ }^{(20)}$ investigated NM23-H1 expression in colorectal carcinoma and proposed the following scoring system for immunohistochemical expression of this marker: 0 ( $0 \%$ stained cells); 1 (1\%-30\% stained cells); 2 (31\%-50\% stained cells); and 3 (more than $50 \%$ stained cells). Lee et al. ${ }^{(26)}$ assessed NM23-H1 expression in neoplastic colorectal tissue and divided the sample into strongly positive (more than $50 \%$ stained cells), weak or moderately positive (less than $50 \%$ stained cells), and negative (absence of stained cells). This diverse array of methods for classifying immunohistochemical expression may explain the conflicting results found by different authors ${ }^{(10,20,22,35)}$, including our series.

Expression of the NM23 marker in the present study was significantly higher in tumor tissue than in normal mucosa. This finding suggests that this protein plays a role in the chain of events involved in neoplastic changes. The NM23 gene codifies subunits of nucleoside diphosphate kinase protein involved in cell differentiation ${ }^{(7,24,28)}$. NM23 expression is therefore expected to be increased in processes of cell multiplication. Sarris and Lee ${ }^{(35)}$ analyzed NM23 expression in relation to colorectal carcinoma liver and lymph node metastases and also identified higher marker expression in tumor tissue than in tumor-adjacent nonneoplastic mucosa.

In the present study, NM23 expression was similar in different degrees of colorectal carcinoma differentiation. Lindmark ${ }^{(27)}$ observed low tissue NM23 expression in poorly differentiated tumors, whereas Cheah et al.(12) and Campo et al. ${ }^{(11)}$ studied expression of the NM23 protein in colorectal carcinoma and did not find any differences in the expression of this marker concerning degree of cell differentiation.

Expression of the NM23 protein in our series was similar among tumor samples, regardless of angiolymphatic and/or perineural invasion. Yamaguchi et al. ${ }^{(39)}$ found no relationship between marker expression and vascular and/or lymphatic invasion. In contrast, Royds et al. ${ }^{(34)}$ identified reduced expression of the NM23 protein in patients with vascular invasion.

In the present series, expression of NM23 markers showed no significant difference regarding tumor clinical staging. Martinez et al. ${ }^{(31)}$ analyzed expression of NM23-H1 and NM23-H2 proteins in relation to TNM stages. The authors found higher NM23-H1 and NM23-H2 expression in early-stage tumors, which include TNM stages I and II. Tannapfel et al. ${ }^{(37)}$ assessed expression of the NM23 protein vs tumor staging and verified that NM23 expression was less intense in more advanced tumors than in early-stage tumors. Lindmark ${ }^{(27)}$ analyzed NM23-H1 expression in colorectal carcinoma, considering tumor staging according to Dukes' classification, and found no correlation between marker expression and different tumor stages.

In the study by Tannapfel et al. ${ }^{(37)}$, expression of the NM23-H1 protein in colorectal carcinomas was lower in patients with lymph node metastasis. This finding suggests a protective effect of NM23 expression against lymph node metastasis. On the other hand, Lee et al. ${ }^{(26)}$ and Sarris and Lee ${ }^{(35)}$ did not identify a relationship between NM23 expression and the occurrence of lymph node metastases. Garinis et al. ${ }^{(20)}$ assessed NM23-H1 expression by PCR in 58 colorectal carcinomas and verified that low gene expression was associated with the occurrence of lymph node metastasis. In our series, the analysis of NM23 expression revealed a higher incidence of metastatic lymph nodes in patients with low protein expression, although this result did not reach statistical significance. This finding suggests a potential protective effect of the NM23 protein, i.e., NM23 expression may be associated with lower incidence of lymph node metastasis. However, the mechanism by which increased marker expression correlates with reduced occurrence of metastases is not fully understood ${ }^{(38,40)}$. Yamaguchi et al. ${ }^{(39)}$ showed an association between NM23 gene and cell proliferation. Thus, one may speculate that tumors with increased NM23 expression will have lower cell proliferation and, consequently, better prognosis.

The present series did not show an association between occurrence of liver metastases and expression of the NM23 protein in colorectal carcinoma tissue. This may have been due to a limited number of patients presenting liver metastases at some stage during the course of the disease, since only 
patients with synchronous metastases were included in our study. Similarly, Lee et al. ${ }^{(26)}$ investigated expression of the NM23-H1 protein in 146 colorectal tumors and found no association between the occurrence of liver metastases and protein expression. On the other hand, Delektorskaya et al. ${ }^{(16)}$, Berney et al. ${ }^{(7)}$ and Garinis et al. ${ }^{(2)}$ identified increased NM23 expression in patients with liver metastases, whereas Ayhan et al ${ }^{(4)}$ identified reduced NM23 expression in patients with liver metastases and advanced-stage tumors. Yamaguchi et al. ${ }^{(39)}$ analyzed NM23 expression in 36 colorectal tumors, and its correlation with liver metastases, and observed that tumors with increased NM23 messenger RNA expression were associated with a lower incidence of metastases. Berney et al. ${ }^{(7)}$ investigated NM23 expression in 58 colorectal cancer patients and identified a significant correlation between NM23 tissue expression and occurrence of liver metastases.

In the present study, overall and disease-free survival rates were higher in patients with increased NM23 expression. This finding is consistent with the prognostic role of a marker, which is considered a protector against the occurrence of metastases. Campo et al. ${ }^{(11)}$ evaluated the loss of heterozygosity of NM23 in relation to patient survival, but found no significant differences. Along the same lines, Royds et al. ${ }^{(34)}$ and Berney et al.(7) identified longer survival among patients with increased NM23 expression. In contrast, Cheah et al. ${ }^{(12)}$, Lee et al. ${ }^{(26)}$ and Lindmark ${ }^{(27)}$ found no relationship between NM23-H1 expression and tumor recurrence or patient survival.

The present study showed a significant association between tissue expression of the NM23 protein and disease-free interval in patients who underwent curative surgery for colorectal carcinoma. NM23 expression was also higher, albeit not statistically significant, in patients with lower overall mortality and in those with fewer lymph node metastases, findings which corroborate the potential protective effect of the NM23 protein. Nonetheless, further studies are warranted to confirm the relevance of the NM23 protein in the prognosis of patients operated on for colorectal carcinoma.

\section{ACKNOWLEDGEMENT}

The authors thank Fernando Soares, $\mathrm{PhD}$ and Carlos Bacchi, $\mathrm{PhD}$, for their technical support.

Oliveira LA, Artigiani-Neto R, Waisberg DR, Fernandes LC, Lima FO, Waisberg J. Expressão da proteína NM23 no carcinoma colorretal preparado em TMA (tissue microarray): associação com metástases e sobrevivência. Arq Gastroenterol. 2010;47(4):361-7.

RESUMO - Contexto - O NM23, denominado de gene supressor de metástases, pode estar relacionado com o prognóstico em doentes com carcinoma colorretal. Objetivos - Analisar a expressão do marcador tumoral NM23 relacionando-a com a presença de metástases linfonodais e hepáticas e com a sobrevivência dos doentes operados por carcinoma colorretal. Método - Cento e trinta doentes operados por carcinoma colorretal foram analisados. Blocos de "tissue microarray" foram obtidos com tecido neoplásico e com mucosa não neoplásica adjacente ao tumor e submetidos ao estudo imunoistoquímico com o anticorpo monoclonal NM23. A imunoexpressão foi avaliada por método semiquantitativo, com contagem do percentual de células coradas. Os resultados encontrados foram relacionados com as características morfológicas e histopatológicas do carcinoma colorretal, presença de metástases linfonodais e hepáticas, estádio e sobrevivência dos doentes. O estudo estatístico foi realizado com os testes de Mann-Whitney, Kruskal-Wallis e exato de Fisher. A análise da sobrevivência foi calculada pelo método de Kaplan-Meier e pelo teste de long-rank. Resultados - A expressão do marcador NM23 foi maior no tecido do carcinoma colorretal do que na mucosa não-neoplásica adjacente $(P<0,0001)$. A expressão da proteína NM23 não apresentou relação com o grau de diferenciação celular $(P=0,57)$, invasão vascular $(P=0,85)$, invasão linfática $(P=0,41)$, infiltração perineural $(P=0,46)$, estádio $(P=0,19)$, metástases linfonodais $(P=0,08)$ ou metástases hepáticas $(P=0,59)$. A sobrevivência livre de doença mostrou relação significante $(P=0,01)$ com a intensidade de imunoexpressão da proteína NM23 no tecido do carcinoma colorretal, e a sobrevivência global não mostrou relação com a expressão da proteína NM23 $(P=0,13)$. Conclusões - A expressão da proteína NM23 foi mais intensa no tecido neoplásico do carcinoma colorretal do que na mucosa não-neoplásica adjacente. A expressão da proteína NM23 não se relacionou com os aspectos morfológicos, presença de metástases linfonodais ou hepáticas, estádio do carcinoma colorretal ou com a sobrevivência global. A sobrevivência livre de doença foi maior nos doentes com expressão aumentada do gene supressor de metástases NM23.

DESCRITORES - Neoplasias colorretais. Carcinoma. Marcadores biológicos de tumor. Antígenos CD. Nucleosídeo NM23 difosfato quinases. Prognóstico. 


\section{REFERENCES}

1. Andrade VP, Cunha IW, Silva EM, Ayala F, Sato Y, Ferreira S, Nascimento $\mathrm{CF}$, Soares FA. O arranjo em matriz de amostras teciduais (tissue microarray): larga escala e baixo custo ao alcance do patologista. J Bras Patol Med Lab. 2007;43:55-60

2. Anwar S, Frayling IM, Scott NA, Carlson GL. Systematic review of genetic influences on the prognosis of colorectal cancer. Br J Surg. 2004;91:1275-91.

3. Astler VB, Coller FA. The prognostic significance of direct extension of carcinoma of the colon and rectum. Ann Surg. 1954;139:846-52.

4. Ayhan A, Yassui W, Yokozaki H, Kitadai Y, Tahara E. Reduced expression of NM23 protein associated with advanced tumor stage and distant metastases in human colorectal carcinomas. Virchows Arch B Cell Pathol Incl Mol Pathol. 1993;63:213-8.

5. Baili P, Micheli A, De Angelis R, Weir HK, Francisci S, Santaquilani M, Hakulinen T, Quaresmas M, Coleman MP. Life tables for world-wide comparison of relative survival for cancer (CONCORD study). Tumori. 2008;94:658-68.

6. Bazan V, Migliavacca M, Zanna I, Tubiolo C, Corsale S, Calò V, Amato A, Cammareri P, Latteri F, Grassi N, Fulfaro F, Porcasi R, Morello V, Nuara RB, Dardanoni G, Salerno S, Valerio MR, Dusonchet L, Gerbino A, Gebbia N, Tomasino RM, Russo A. DNA ploidy and S-phase fraction, but not p53 or NM23-H1 expression, predict outcome in colorectal cancer patients. Result of a 5-year prospective study. J Cancer Res Clin Oncol. 2002;128:650-8

7. Berney CR, Fisher RJ, Yang J, Russel PJ, Crowe PJ. Protein markers in colorectal cancer: predictor of liver metastasis. Ann Surg. 1999;230:179-84.

8. Berney CR, Fisher RJ, Yang J, Russel PJ, Crowe PJ. Genomic alterations (LOH, $\mathrm{MI}$ ) on chromosome 17q21-23 and prognosis of sporadic colorectal cancer. Int J Cancer. 2000;89:1-7.

9. Boyle P. Favorable trends in cancer mortality in the European Union but no room for complacency. Ann Oncol. 2008;19:605-6.

10. Brenner AS, Thebo JS, Senagore AJ, Duepree HJ, Gramlich T, Ormsby A, Lavery IC, Fazio VW. Analysis of both NM23-H1 and NM23-H2 expression identifies "at-risk" patients with colorectal cancer. Am Surg. 2003;69:203-8.

11. Campo E, Miquel R, Jares P, Bosch F, Juan M, Leone A, Vives J, Cardesa A, Yague J. Prognostic significance of the loss of heterozygosity of NM23-H1 and p53 genes in human colorectal carcinomas. Cancer. 1994;73:2913-21.

12. Cheah PY, Cao X, Eu KW, Seow-Choen F. NM23-H1 immunostaining is inversely associated with tumour staging but not overall survival or disease recurrence in colorectal carcinomas. Br J Cancer. 1998;77:1164-8.

13. Chen WC, Lin MS, Zhang BF, Fang J, Zhou Q, Hu Y, Gao HJ. Survey of molecular profiling during human colon cancer development and progression by immunohistochemical staining on tissue microarray. World J Gastroenterol. 2007;13:699-708

14. Cohn KH, Wang FS, Desoto-LaPaix F, Salomon WB, Patterson LG, Arnold MR, Feldman JG, Levy AT, Leone A, Steeg PS. Association of nm23 allelic deletions with distant metastases in colorectal carcinoma. Lancet. 1991;338:722-4.

15. Coleman MP, Quaresma M, Berrino F, Lutz JM, De Angelis R, Capocaccia R, Baili P, Rachet B, Gatta G, Hakulinen T, Micheli A, Sant M, Weir HK, Elwood JM, Tsukuma H, Koifman S, E Silva GA, Francisci S, Santaquilani M, Verdecchia A, Storm HH, Young JL; CONCORD Working Group. Cancer survival in five continents: a worldwide population-based study (CONCORD). Lancet Oncol. 2008;9:730-56

16. Delektorskaya VV, Perevoshchikov AG, Kushlinskii NE. Immunohistological study of nm23 and C-erB-2 expression in primary tumor and metastases of colorectal adenocarcinoma. Bull Exp Biol Med. 2003;135:489-94.

17. Demirbas S, Sücüllü I, Yildirim S, Celenk T. Influence of the c-erb B-2, nm23, Bcl-2 and p53 protein markers on colorectal cancer. Turk J Gastroenterol 2006;17:13-9.

18. Elagoz S, Egilmez R, Koyuncu A, Muslehiddinoglu A, Arici S. The intratumoral microvessel density and expression of bFGF and nm23-H1 in colorectal cancer. Pathol Oncol Res. 2006;12:21-7.

19. Futamura M, Takagi Y, Koumura H, Kida H, Tanemura H, Shimokawa K, Saji S. Spread of colorectal cancer micrometastases in regional lymph nodes by reverse transcriptase-polymerase chain reactions for carcinoembrionic antigen and cytokeratin 20. J Surg Oncol. 1998;68:34-40.
20. Garinis GA, Manolis EN, Spanakis NE, Patrinos GP, Peros G, Menounos PG. High frequency of concomitant $\mathrm{nm} 23$ - $\mathrm{H} 1$ and E-cadherin transcriptional inactivation in primary non-inheriting colorectal carcinomas. J Mol Med. 2003;81:256-63.

21. Hadziavdic V, Eminovic I, Asceric M, Komel R. Familial adenomatous polyposis: analysis of genetic instability of microsatellites loci and genetic alternations of tumor suppressor genes. Bosn J Basic Med Sci. 2008;8:160-4.

22. Haut M, Steeg PS, Wilson JK, Markowitz SD. Induction of nm23 gene expression in human colonic neoplasms and equal expression in colon tumors of high and low metastatic potential. J Natl Cancer Inst. 1991;83:712-6.

23. Heide I, Thiede C, Poppe K, de Kant E, Huhn D, Rochlitz C. Expression and mutational analysis of $\mathrm{Nm} 23-\mathrm{H} 1$ in liver metastases of colorectal cancer. Br J Cancer. 1994;70:1267-71.

24. Kim HJ, Kang HJ, Lee H, Lee ST, Yu MH, Kim H, Lee C. Identification of S100A8 and S100A9 as serological markers for colorectal cancer. J Proteome Res. 2009;8:1368-79.

25. Kononen J, Budendorf L, Kallioniemmi A, Barlund M, Schraml P, Leighton S, Torhorst J, Mihatsch MJ, Sauter G, Kallioniemi OP. Tissue microarrays for highthroughput molecular profiling of tumor specimens. Nat Med. 1998;4:844-7.

26. Lee JC, Lin YJ Chow NH, Wang ST. Reappraisal of the role of NM-23 H1 in colorectal cancers. J Surg Oncol. 2001;76:58.

27. Lindmark G. NM23-H1 immunohistochemistry is not useful as predictor of metastatic potential of colorectal cancer. Br J Cancer. 1996;74:1413-8.

28. Liu YJ, Yan PS, Li J, Jia JF. Expression and significance of CD44s, CD44v6, and nm23 mRNA in human cancer. World J Gastroenterol. 2005;11:6601-6.

29. Lopez MJ, Monafo WW. Role of extended resection in the initial treatment of locally advanced colorectal carcinoma. Surgery. 1993;113:365-72.

30. Madbouly KM, Senagore AJ, Mukerjee A, Delaney CP, Connor J, Fazio VW. Does immunostaining effectively upstage colorectal cancer by identifying micrometastatic nodal disease? Int J Colorectal Dis. 2007;22:39-48.

31. Martinez JA, Prevot S, Nordlinger B, Nguyen TM, Lacarriere Y, Munier A Lascu I, Vaillant JC, Capeau J, Lacombe ML. Overexpression of nm23-H1 and NM23-H2 genes in colorectal carcinomas and loss of nm23-H1 expression in advanced tumour stages. Gut. 1995;37:712-20.

32. Myeroff LL, Markowitz SD. Increased nm23-H1 and nm23-H2 messenger RNA expression and absence of mutations in colon carcinomas of low and high metastatic potential. J Natl Cancer Inst. 1993;85:147-52.

33. Nasser JA, Falavigna A, Ferraz F, Duigou G, Bruce J. Transcription analysis of TIMP-1 and NM23-h1 genes in glioma cell invasion. Arq Neuropsiquiatr 2006;64:774-80.

34. Royds JA, Cross SS, Silcocks PB, Scholefield JH, Rees RC, Stephenson TJ. Nm23 "anti-metastatic" gene product expression in colorectal carcinoma. J Pathol 1994;172:261-6.

35. Sarris M, Lee CS. $\mathrm{nm} 23$ protein expression in colorectal carcinoma metastasis in regional lymph nodes and the liver. Eur J Surg Oncol. 2001;27:170-4.

36. Silveira EJ, Oliveira MC, Morais ML, Queiroz LM, Costa AL. Expressão da proteína nm23 em carcinoma de células escamosas de língua metastático e nãometastático. Rev Bras Otorrinolaringol. 2008;74:356-9.

37. Tannapfel A, Köckerling F, Katalinic A, Wittekind C. Expression of nm23-H1 predicts lymph node involvement in colorectal carcinoma. Dis Colon Rectum. 1995;38:651-4

38. Wang L, Patel U, Ghosh L, Chen HC, Banerjee S. Mutation in the nm 23 gene is associated with metastasis in colorectal cancer. Cancer Res. 1993;53: 717-20.

39. Yamaguchi A, Urano T, Fushida S, Furukawa K, Nishimura G, Yonemura Y, Miyazaki I, Nakagawara G, Shiku H. Inverse association of nm23-H1 expression by colorectal cancer with liver metastasis. Br J Cancer. 1993;68:1020-4.

40. Yang YQ, Wu L, Chen JX, Sun JZ, Li M, Li DM, Lu HY, Su ZH, Lin XQ, Li JC. Relationship between $\mathrm{nm} 23-\mathrm{H} 1$ genetic instability and clinical pathologica characteristics in Chinese digestive system cancer patients. World J Gastroenterol. 2008;14:5549-56.

41. Yao T, Takata M, Tustsumi S, Nishiyama K, Taguchi K, Nagai E, Tsuneyosh M. Phenotypic expression of gastrointestinal differentiation makers in colorecta adenocarcinomas with liver metastasis. Pathology. 2002;34:556-60.

Received 24/8/2009. Accepted 10/5/2010. 